\title{
Protection of Personal Non-Property Rights: International, National and Foreign Experience
}

\author{
Marine Zaurovna Abesalashvilii ${ }^{1}$, Lidiya Nikolaevna Burkova ${ }^{2}$, Tutarishcheva Svetlana Muratovna ${ }^{3} \&$ Irina \\ Askerovna Gasheva ${ }^{4}$ \\ ${ }^{1}$ Candidate of law, associate professor, head of civil and labor law, Adyghe State University, Maikop, Russian \\ Federation \\ ${ }^{2}$ Candidate of law, Associate Professor of civil and labor law, Adyghe State University, Maikop, Russian \\ Federation \\ ${ }^{3}$ Candidate of pedagogical sciences, associate professor of civil and labor law, Adyghe State University, Maikop, \\ Russian Federation \\ ${ }^{4}$ Assistant professor of the Civil and arbitration process, Adyghe State University, Maikop, Russian Federation \\ Correspondence: Marine Zaurovna Abesalashvili, Pervomajskaja st. 208, Maikop, 385000, Russian Federation.
}

Received: February 28, 2015 Accepted: March 20, 2015 Online Published: April 26, 2015

doi:10.5539/res.v7n6p267 URL: http://dx.doi.org/10.5539/res.v7n6p267

\begin{abstract}
This article explores the regulatory framework aimed at ensuring personal non-property rights of citizens, as well as problems of improving the legal regulation. We examined provisions adopted in the international law, the Russian civil law, foreign law, approaches developed in law enforcement and opinions, formulated in modern scientific literature. The author showed the trends towards convergence of norms, which regulate personal non-property rights in legislation of different countries. In these standards the author points out strict adherence to fundamental principles, enshrined in international human rights instruments, which determines a possibility of unification of legal regulation of the examined area of public relations. Examples of international experience, examined by the author, also offer effective approaches to compensation for moral damages in cases of violation of non-property rights. The author's conclusions expressed in this article can be used in law enforcement and scientific activities.
\end{abstract}

Keywords: personal non-property relations, intangible benefits, personal non-property rights, civil law

\section{Introduction}

Nowadays the position of the individual in society, the scope of his/her freedom is expressed not only and not just in financial possibilities, but in a possibility of implementing the so-called personal non-property rights, the quantity, quality and extent of which constitute a meaningful description of a position of the individual in a society and state. In a society, where ideals of justice, humanity and democracy dominate, public provision of legal safeguards for protection of rights and legitimate personal, intangible interests, along with protection of substantive rights, is an indicator of the state's attitude towards basic democratic values.

A considerable intensification of research on various methods of protection of personal non-property rights and intangible benefits of individuals can be explained by the fact that it is the intangible benefits that constitute all spheres of existence, development and implementation of the individual, determine both inner well-being of citizens and spiritual and moral potential of the Russian society. Awareness of paramount importance of personal, private life penetrates the modern Russian society more and more.

Appearance of scientific researches on the institution of personal non-property rights seems to be associated with the beginning of the debate of late XIX - early XX centuries concerning antagonism of freedom and equality in terms of increasing social inequality, turning into arbitrariness of an individual private owner.

Researchers of the institution of intangible benefits in the civil law of pre-revolutionary Russia, the Soviet and Russian period of development point out, that the general provision concerning compensation for inflicted damages, interpreted in judicial practice exclusively as a property one, was gradually modified and the law started to protect the rights of citizens in the field of intangible benefits. 
For example, in Articles 644-683, Chapter 6, "On the right to remuneration for any incurred loss or damage" of the first part of volume $\mathrm{X}$ of the Code of Civil Laws, fee for dishonour or payment of compensation to a victim as a result of personal insult or offence was established, for example, for loan damages compensation was allowed for moral inflicted damage (Art. 670) (Code of Laws, 1900).

The draft Civil Code, published at the end of the XIX century, allowing compensation for non-pecuniary damage, has been criticized by Petrazhitsky (1900), while Schroeter V. N., on the contrary, proposed to amplify legislation to combat defamation of reputation by a claim to terminate these actions in absence of the violator's fault (Schroeter, 1915). Porkrovsy I. A. in his works proved to Shershenevich G. F. that it is not enough to prosecute for violation of intangible benefits (honour and dignity), but it is necessary to introduce special civil laws providing protection and preservation of these benefits as well (Pokrovsky, 1916).

Civil law of the Civil Code in 1922 did not envisage specific ways to protect honour and dignity, as the use of criminal law measures against crimes against life, health, freedom and dignity was considered sufficient (Sec. 6 of the Criminal Code of the RSFSR, 1926) (Fokov, 2013).

Later in the Soviet period of the country's development, the problems of civil protection of intangible benefits were addressed by scientists, but without fundamental research of objects of personal rights. Fleyshits E. A proposed to include protection of personal rights in civil law (Fleyshits, 1941), regardless of the violator's fault of honour and dignity of an individual, this was legislatively consolidated only in Art. 7 on Principles of Civil Legislation of the USSR and the Union Republics "Protection of honour and dignity." Subsequently, Art. 7 of the Civil Code of the RSFSR in 1964 recognized the said institution, but conflicting jurisprudence demanded clarification of the Supreme Court of the USSR on December 17, 1971 N 11 "On application of Art. 7 Principles of Civil Legislation of the USSR and the Union Republics on protection of honour and dignity of citizens and organizations in the jurisprudence" (Compilation of rulings of the Plenum of Supreme Court of the USSR (1924-1986), 1987).

The study of a large number of researchers' works shows that science has not developed a unique approach to a number of problems, among which, in the author's opinion, is the basic lack of understanding by many scientists of the role of the institution of non-pecuniary damage compensation, as a way to protect personal non-property rights, acting as a certain instrument of social justice in property relations.

\section{Research Methodology}

Methods used in the presented article should define those properties of civil legal relations, which have only legal value, as well as its functional (as a legal means) potential, and a substantial (structural) sense. According to the author, to conduct a qualitative comprehensive scientific research, it is necessary not to affiliate the institution of personal non-property rights solely with civil rights, as the majority of these rights have been legally documented under international humanitarian, constitutional law, a number of political, legal and public theories. Based on the above said, the author decided to use the methods of cognition, inherent to the mentioned sciences and theories, namely systemic, historical, dialectical, legalistic, comparative and jurisprudential. It is this combination of divergent methodological techniques and methods, which is designed to achieve not only theoretical but also applied research results, will allow making evidence-based conclusions and noteworthy suggestions for improving the current regulation.

Results: Return of the interest to the topic of protecting honour, dignity and business reputation, appears to be related primarily to two key events: the first one is the adoption of the Federal Act of July 2, 2013 No. 142-FZ "On Amendments to subsection 3 section I of the Civil Code of the Russian Federation "(hereinafter-Federal Act No. 142-FZ); second one is the release of the Ruling of the Constitutional Court of the Russian Federation dated July 9, $2013 \mathrm{~N}$ 18-P "On the case of constitutionality check of the provisions of paragraphs 1, 5 and 6 of Article 152 of the Civil Code of the Russian Federation in connection with the complaint of a citizen Krylov E. V.". Consider the content of these documents.

After the entry into force (October 1, 2013) of the Federal Act No. 142-FZ, Art. 152 of the Civil Code of the Russian Federation (hereinafter - the Civil Code) has undergone significant changes. Leaving aside structural and quantitative changes, we point out that a significant number of meaningful innovations were introduced into this article, the main innovation-recognition of differences of defamation on the Internet from defamation in other areas in the legislation, particularly regarding ways of protection against it.

For example, if information that discredits business reputation of a citizen, became widely known and refutation cannot be brought to the public's attention, the citizen has the right to demand removal of the corresponding information, as well as restraint or prohibition of its further spread (Commentary to the Federal Act of July 2, 
2013 No. 142- FZ "On Amendments to subsection 3 of section I of the Civil Code of the Russian Federation", Legal reference system "ConsultantPlus").

These measures may include seizure and destruction of copies of physical media containing the above information without any compensation, unless deletion of the relevant information is not possible otherwise, but these copies must be made in order to be entered into civil circulation (p. 4, Art. 152 of the Civil Code of the Russian Federation as amended in the Federal Act No. 142-FZ). The mentioned norm has become the most discussed by the public, including scientists. Some experts believe that the introduced provision leads to censoring of media materials, creates additional difficulties for publication of "unpleasant" materials, primarily for government officials and high level civil servants, politicians and public figures (Svintsova, 2013), and does not protect "ordinary" citizens from real, intentional defamation.

In accordance with p. 5, Art. 152 of the Civil Code (as amended in the Federal Act No. 142-FZ), if information that discredits business reputation of a citizen, became available on the Internet after it had been disseminated, the citizen has the right to, in addition to refutation, request removal of the corresponding information with a method of bringing the refutation to Internet users' attention.

The limitation period, according to requirements presented in connection with distribution of any untrue information about the citizen in the media, is one year from the date of publication of such information (p. 10, Art. 152 of the Civil Code as amended in the Federal Act No. 142-FZ).

The formulation of the p. 11, Art. 152 of the Civil Code (as amended in the Federal Act No. 142-FZ) is surprising: "Provisions of this article on protection of business reputation of a citizen, except for provisions on moral damage, respectively, are applied to protect reputation of a legal entity." At the same time, legislators did not envisage provisions on compensation for moral (reputational) damage. Therefore, an entity may rely on compensation for property damage- - losses (actual damages and lost profits), but not on compensation for moral damage. Thus, the issue of compensation for "moral" (reputational) damage to organizations remains extremely relevant, and thus in practice there will be asymmetric judicial decisions, or in connection with normative consolidation of such formulation, a shift to a position of complete denial of moral damage to legal entities with defamation is possible.

In addition, the newly introduced paragraph contradicts to positions of the highest courts of the Russian Federation. Thus, in p. 15 of the Ruling of the Plenum of the Supreme Court of 24 February 2005 No. 3 "On judicial practice in cases of protection of honour and dignity of citizens, as well as of business reputation of citizens and legal entities," it is stated that the rules governing compensation for moral damage in connection with disseminating information discrediting business reputation, also apply in cases of disseminating such information in respect of a legal entity (Plenum of the Armed Forces of February 24, 2005). In the Ruling of the Presidium of the Supreme Arbitration Court of the Russian Federation of July 17, 2012 No. 17528/11 in the case No. A45-22134/2010 it is also stated that, in accordance with paragraphs 5 and 7 Art. 152, p. 2, Art. 1099 of the Civil Code, a legal entity on a par with a citizen has the right to claim losses and moral (reputational) damage inflicted by dissemination of information defaming their business reputation. The organization is entitled to demand compensation for such damages if the general conditions of tortious liability are proven. These conditions include the following: wrongfulness of the act on the part of the defendant, adverse consequences of these actions for the plaintiff, as well as a causal link between actions of the defendant and occurrence of adverse effects to the plaintiff.

The above-cited examples of court orders ascertain an urgent need for legislative recognition of the possibility of compensation for reputational harm to legal entities when disseminating untrue information (defamation) and it would be quite natural and timely.

The second fundamental guideline in resolving disputes on protection of honour, dignity and business reputation became adoption of The ruling of the Constitutional Court of the Russian Federation dated July 9, 2013 No. 18-P "On the case of constitutionality check of provisions of paragraphs 1,5 and 6 of Article 152 of the Civil Code of the Russian Federation in connection with the complaint of a citizen Krylov E. V.". The reason for taking legal recourse was denial of the applicant's claim against the company - the owner of the forum with the requirements to remove defamatory information from the website and indemnify inflicted moral damage. The court dismissed the stated requirements, considering that actual authors of offensive comments should answer to that, not the administration of the forum. All higher courts upheld that decision without any changes (Ruling of the Constitutional Court of the Russian Federation of 09. 07. 2013 No. 18-P, 2013).

The Constitutional Court of the Russian Federation decided that such obligation should be extended to all owners of Internet resources: “... If information, defamatory to a citizen, posted on the website on the "Internet", 
is recognized by the court to be untrue, the website owner or the authorized person, who is responsible for publishing information on this website should be obliged to remove such information at the request of the victim." Thus, the Court pointed out that otherwise it would effectively mean denial of protection of honour and dignity of a citizen, his/her good name and reputation, besides, methods of protection, for example those, involving preservation of this information on the website and at the same time placement of the court decision that refutes it, significantly reduce protection effectiveness, especially when the court concludes that it is impossible to find the disseminator.

At the same time, the Constitutional Court emphasizes that imposing obligations on a website owner to remove defamatory information is not a measure of responsibility for culpable offense, but a legitimate way to protect rights, which implies that a victim may take legal action for protection of violated rights if the website owner refuses to fulfil this obligation on a voluntary basis. In opinion of judges, preference should be given to the victim's interests over interests of owner of the website, so that dignity of the individual would be restored in any case; imposing obligations on the person who has technical capability to remove the information declared by the court to be untrue without prejudice to their rights and legitimate interests, obligations to take necessary actions (according to the court decision that entered into force) as soon as he/she learned about, cannot be considered as an excessive encumbrance or as a disproportionate restriction of his/her rights.

Thus, as the Constitutional Court judges rightly pointed out, our current legislation has long needed introduction of additional regulatory safeguards for protection of honour, dignity and business reputation, which take into account the significant change in ways of disseminating information and meet conditions of information movement on the Internet, which is often comparable in scope of audience with mass media activities, besides the fact that availability of technical possibilities for abuse by unspecified persons in absence of adequate measures to prevent such abuses, increased the risk of non-pecuniary damage by disseminating untrue defaming information about a citizen, and thus - the risk of diminishing dignity of an individual, which is unacceptable.

\section{Discussion}

It is absolutely fairly noted that international rules of law (agreement), which form a part of international and domestic law, can effectively protect rights and legal interests of citizens, legal entities, including personal non-property rights, and provide certainty, stability, consistency, transparency in enforcement.

In preambles of the Universal Declaration of Human Rights of 1948, the International Covenant on Economic, Social and Cultural Rights of 1966, the International Covenant on Civil and Political Rights of 1966, in which the USSR participated as well (the successor is the Russian Federation), it is declared that "dignity is inherent to all members of the human family" (International Public Law: Collection of documents, 1996). Art. 1 of the Universal Declaration of Human Rights underlines: "All human beings are born free and equal in dignity and rights", and the World Conference on Human Rights, held in Vienna in 1993, adopted the Vienna Declaration and Programme of Action, which affirmed that "all human rights derive from the dignity and worth inherent in the human person "(Vienna Declaration and Programme of Action, 1993).

There is hardly any doubt of the importance of the ruling adopted by the Plenum of the Supreme Court of the Russian Federation dated June 27, 2013 No. 21 "On the use of general jurisdiction of the Convention for the Protection of Human Rights and Fundamental Freedoms of 4 November 1950 and the Protocols thereto by the courts" (Plenum of the Supreme Court of the Russian Federation dated 27. 06. 2013 No. 21, 2013) for further formation and development of the Russian law enforcement in relation to personal non-property rights.

The definition of restrictions on rights and freedoms (interference with rights and freedoms), formulated in Sec. 5 of the Ruling, is of special relevance. It implies that any decisions, action (inaction) of state authorities, local self-government bodies, officials, state and municipal employees and other persons, adoption or implementation (non-implementation) of which in respect to the person claiming alleged violation of his rights and freedoms, leads to creation of obstacles for his executing rights and freedoms. Sec. 5 of the Ruling provides the use of the image of a citizen without his consent as an example of restrictions on rights and freedoms identified in the Court's practice.

Due to p. 3, Art. 55 of the Constitution of the Russian Federation and the provisions of the Convention, any restriction on the rights and freedoms should be based on the federal law, pursue a socially important legitimate aim and be necessary in a democratic society. Failure to comply with any of these criteria is a violation of human rights and freedoms. Some human rights and freedoms guaranteed by the Convention may not be restricted in any way, such as the right not to be tortured.

It is necessary to point out great practical significance of the indication, made in p. 8 of the Ruling, on obligatory 
grounding by courts of restrictions on rights and freedoms of the individual with evaluation of findings of fact, when conducting legal investigation.

Having shown the importance of the fundamental international instruments for the protection of personal non-property rights, it is logical and useful to refer to foreign experience.

Personal non-property rights to life, health, privacy, personal and family secrets are absolute subjective rights in Germany and individual rights in France. These rights are analogues of personal non-property rights in the Russian law. Recognition of life, health, privacy, personal and family secrets being objects of absolute subjective rights and objects of the individual rights suggests that foreign legislation differentiates concepts of "intangible benefits" and "personal non-property rights", which also confirms the validity of the conclusions of Apranich M. L., Krasavchikova L .O., Maleina M. N., Yermolova O. N. on inadmissibility of combining personal non-property rights and intangible benefits in the provisions of one article (Palkina, 2011), as it is done in the Civil Code of the Russian Federation.

The Civil Code of France contains provisions designed to respect private life, rules of physical integrity, rules on protection of the biosocial components of the individual (rules relating to the ban on assault of man as a species, the study of human genetic characteristics and identification by genetic prints). Similar provisions are contained particularly in the Civil Code of the Province of Quebec, namely the rules on privacy and prohibition of genetic research on human beings. The doctrine and jurisprudence of Germany and Italy also develop in this direction (Zaman, 2009). Incorporation of the new personal non-property rights, appeared as a result of the development of science and technology, posing threats to human rights violations, in the texts of the civil codes of the countries of the Roman-Germanic legal system proves dynamic development and improvement of foreign civil law, which timely allows preventing violation of moral rights.

In the US the right of privacy is a complex of personal non-property rights and benefits, including the right to solitude, the right to privacy. However, in the complex of these rights the right of publicity is allocated, which refers to a set of property rights that allow extracting financial benefits from the use of their name, image (Kolosov \& Schwartz, 2008). Thus, in the USA personal non-property rights have a wider meaning, as property rights are included in the set of personal non-property rights.

Compensation for moral damage is one of the most common forms of civil liability for violations of personal non-property rights in the countries, forming part of the Anglo-American and Roman-Germanic legal system. In the US, the question of compensation for moral damage is solved on the basis of precedents, taking into account the individual characteristics of the victim's mentality. In the UK, the tariff scheme of compensation is developed depending on the severity of consequences (Palkina, 2011).

In Germany, the Institution of non-pecuniary compensation for damage caused by violation of personal non-property rights was formed as well. German Civil Code (BGB) 1896 contains $§ 253$, according to which monetary compensation shall be recovered for non-pecuniary damage in the event of encroachment on "physical integrity or health", "restriction of freedom", forcing a woman to concubinage ( $\$ 847$ BGB); in case of the groom's refusal from the engagement if cohabitation took place of "respectable Bride" and her fiancé (p. 1, 1300 BGB). Currently, cases of encroachment on physical integrity, health, freedom or sexual integrity determine a possibility of the corresponding demand of "fair compensation in money," according to the current provision $\S 253$, p. 2 BGB. The Federal Court of Germany in the absence of a legislative definition of the concept gave a definition of the claim for non-pecuniary damage as "a special kind of claim with a double function: it must provide adequate compensation to the victim (Ausgleich) for the non-property damage, and at the same time take into account that the offender must provide personal satisfaction to the victim (Genugtuung) for what he/she did to him/her" (Rem, 1962). Thus, the court in the case of compensation for non-property damage highlights its two main functions of "compensation" and "personal satisfaction" rather than the idea of restoring the non-property rights which is provided in the Civil Code of the Russian Federation. By compensating non-property damage, the Court of Germany tries to satisfy the sense of derision suffered from encroachments on his/her honour, dignity and other intangible benefits that may already be a real benchmark for the Russian court in determining the amount of monetary compensation.

\section{Conclusion}

The above study of the Russian legislation (taking into account the latest changes) and international experience suggest that the lack of theoretical and legal development of the institution of compensation for moral damage in Russia, unlike legislation of foreign countries, reduces the value of this method of protection, which highlights the need for further development of this Institution taking into account international experience, which, in its turn, will lead to adequate protection of personal non-property rights. 
The comparison of Russian and foreign experience of legal regulation of personal non-property relations with norms of civil and family law demonstrates the universality of personal non-property rights and its common understanding. It would be premature to declare legal regulation of personal non-property relations in Russia and foreign countries identical and uniform. Foreign legislation is characterized by innovations, unknown to the Russian legislation, as it allows regulating personal non-property relations by means of a contract, establishes new personal non-property rights, arising from the development of science and technology, in a timely manner, allows compensating moral damage resulting from any violation of personal non-property rights, on the basis of a necessity to satisfy feelings of the victim. For example, the technique of compensating moral damage in Germany is based on that. These circumstances indicate the progressive experience of legal regulation of personal non-property relations in foreign countries.

Taking into account the above said, it seems appropriate to borrow foreign experience of legal regulation of non-property relations.

\section{References}

Code of Laws of the Russian Empire (Vol. 10). (1900). Saint-Petersburg.

Fleyshits, E. (1941). Individual rights in the civil law of the USSR and the capitalist countries. Moscow.

Fokov, A. (2013). Protection of honour, dignity and business reputation, protection of privacy of the citizen and other intangible benefits: Innovations of the Civil Code of the Russian Federation. Russian judge, 9, 2-6.

Kolosov, V., \& Schwartz, M. (2008). The right to images in Russian law, taking into account international experience. Copyright and Related Rights reserved, 3, 5 .

Palkina, T. (2011). Legal regulation of personal non-property relations in civil and family law of foreign countries. Family and housing law, 5, 15-20.

Petrazhitsky, L. (1900). Compensation for non-pecuniary damage in terms of social policy. Pravo. Weekly legal newspaper, 11, 12, 15, 16.

Pokrovsky, I. (1916). The right to honour. In Herald of civil law (pp. 23-320). Petrograd.

Protection of Human Rights and Fundamental Freedoms Convention. Bulletin of international treaties, 3.

Rem, T. (1962). Die Aufgaben des Schmerzensgeldes im Personlichkeitsschutz: Rechtsvergleichende Beitrage zum Schadensrecht. Frankfurt A. M. Berlin.

Reports of rulings of the Plenum of Supreme Court of the USSR (1924-1986). (1987). Moscow.

On the case of constitutionality check of the provisions of paragraphs 1,5 and 6 of Article 152 of the Civil Code of the Russian Federation in connection with the complaint of a citizen Krylov E. V. (2013). Bulletin of the Constitutional Court of the Russian Federation, 6.

On judicial practice in cases of protection of honour and dignity of citizens, as well as of business reputation of citizens and legal entities. (2005). Bulletin of the Supreme Court, 4.

On the use of general jurisdiction of the Convention for the Protection of Human Rights and Fundamental Freedoms of 4 November 1950 and the Protocols thereto by the courts. (2013).

Schroeter, V. (1915). Unfair competition: Studies in honour of Shershenevich G. F. Moscow.

Svintsova, M. (2013). Innovations in the field of protection of honour, dignity and business reputation. Law and Economics, 11, 52-55.

The Vienna Declaration and Programme of Action. (1993). Moscow.

Zaman, S. (2009). Civil status of individuals in Germany, Italy, France and Russia (Synopsis of a thesis). Moscow.

\section{Copyrights}

Copyright for this article is retained by the author(s), with first publication rights granted to the journal.

This is an open-access article distributed under the terms and conditions of the Creative Commons Attribution license (http://creativecommons.org/licenses/by/3.0/). 